\title{
Atípusos periprotetikus femurtörés
}

\author{
DR. DÓZSAI DÁVID, DR. CSONKA ÁKOS, DR. GÁRGYÁN ISTVÁN, DR. VARGA ENDRE
}

\section{ÖSSZEFOGLALÁS}

Az atípusos femurtörések kialakulását elsősorban a hosszú távú biszfoszfonát kezeléssel hozzák összefüggésbe. Az American Society for Bone and Mineral Research (ASBMR) által 2014-ben közzétett ajánlás egyértelmúen meghatározza az atípusos törés definícióját és ebben a periprotetikus törés, mint kizáró tényező szerepel. Ennek ellenére egyre több közlemény számol be arról, hogy egyes periprotetikus femurtörések az atípusos törések karakterisztikájával jelennek meg. Tanulmányunkban egy periprotetikus törést elszenvedett beteg esetén keresztül mutatjuk be, hogy a hosszú távú biszfoszfonát terápia és az atípusos törésforma között korreláció lehet, illetve az atípusos femurtörés periprotetikus formában is jelentkezhet.

\section{Kulcsszavak: $\quad$ Biszfoszfonát kezelés; Femurtörés; Gyógyszer mellékhatás;} Osteoporosis; Periprotetikus törés;

\section{Dózsai, Á. Csonka, I. Gárgyán, E. Varga: Atypical periprosthetic femoral fracture}

The development of the atypical femoral fracture is mainly associated with the long-term use of bisphosphonates. In 2014 a report was published by The American Society for Bone and Mineral Research (ASBMR) which has clearly identified the case definition of the atypical fractures and excluded periprosthetic femoral fractures from it. Even so, several case reports found that periprosthetic femoral fractures can occur with similar characteristics to those of definition of the atypical fractures. The purpose of our study was to feature a case report of an atypical periprosthetic femoral fracture, and its possible correlation between the long-term use of bisphosphonate and atypical fracture form. Thus, atypical femoral fracture can occur in periprosthetic form as well.

Keywords: $\quad$ Diphosphonates - Adverse effects;

Bone density conservation agents - Adverse effects;

Femoral fractures - Chemically induced/Pathology;

Osteoporosis - Complications/Drug therapy;

Periprosthetic fractures - Epidemiology/Etiology; 


\section{BEVEZETÉS}

Az osteoporosis világszerte több százmillió embert súlyt, Magyarországon a lakosság körülbelül 10\%-át (23). A biszfoszfonát tartalmú készítmények használata jelentősen csökkentette az osteoporosis alapú törések rizikóját, és az egészségügyi rendszerre nehezedő terhet (14).

A csontrendszerre kifejtett előnyös hatásuk a törési kockázat csökkentésében nyilvánul meg. Az osteoclastok működését gátolva csökkentik a csont reszorpciót, így a csontszerkezet további leépülését megakadályozva csökken a törések kialakulásának esélye $(9,20)$. Indirekt módon csökkennek a csontban létrejövő mikrofraktúrák, azonban a már korábban keletkezett mikrofraktúrák új csontmátrix-szal történő helyettesítése is zavart szenved. Ez az alapja annak, hogy az atípusos femurtörés (AFT) a biszfoszfonátok több éven át tartó használata mellett új töréstípusként jelent meg $(18,20)$, amelyet egy mesterségesen létrehozott alacsony csontátépülés okoz. Az atípusos femurtörés alacsony energiájú vagy esetenként trauma nélkül létrejövő stressztörés, amelyre sajátos megjelenésű röntgenkép jellemző (22). A 2014-ben megjelent American Society for Bone and Mineral Research ajánlás alapján az atípusos subtrochanterikus és középső harmadi femurtörések esetében a periprotetikus törés, mint kizáró kritérium szerepel (22). Az elmúlt években azonban jelentős számú esettanulmány jelent meg arról, hogy a hosszú távú biszfoszfonát kezelés melletti periprotetikus femurtörések (PFT) atípusos femurtörésekre jellemző morfológiával is előfordulhatnak (3, $5,10,15,16,19)$. Ezeket nevezzük atípusos periprotetikus femurtörésnek (APFT). Az
APFT-k az idősebb generációt érintik, hiszen ezen populációban a biszfoszfonát kezelés mellett gyakori az ízületi implantátum megléte, és egyéb társbetegségek (diabétesz, D-vitamin hiány, proton pumpa inhibitor használat) is szerepelhetnek az anamnézisükben $(1,6)$. Mindezek ismerete mellett az APFT-ek kiváltó oka, etiológiája, diagnosztikus kritériumai és terápiás javaslatai továbbra sem egyértelműen meghatározottak (19).

Tanulmányunkban egy esettanulmányon keresztül mutatjuk be, hogy az atípusos femurtörések ritkán, periprotetikus formában is megjelenhetnek.

\section{ANYAG ÉS MÓDSZER}

A Szegedi Tudományegyetem Traumatológiai Klinikáján prospektív vizsgálat folyik az atípusos femurtörések felismerése, gyógyszeres és mútéti kezelése tekintetében. A vizsgálatok során észleltük, hogy egyes periprotetikus Vancouver B1 töréseknél atípusos törésmintázat figyelhető meg.

2015-ben öt beteget kezeltünk periprotetikus Vancouver B1 törés miatt. Közülük két esetben figyelhettünk meg atípusos törésmintázatot. Anamnézisükben 5 évnél hosszabb ideig tartó biszfoszfonát terápia szerepelt. Az atípusos femurtörések diagnózisának felállításához az American Society for Bone and Mineral Research munkacsoport ajánlásait alkalmaztuk, amely alapján 5 kritériumból legalább 4-nek kell teljesülni (I. táblázat) (22).

A diagnózis felállításához nélkülözhetetlenek az anamnesztikus adatok (időszakos combfájdalom, gyógyszerszedés, társbetegségek), illetve a röntgenfelvételeken az I. táblázatban felsorolt eltérések. 


\section{I. táblázat Az American Society for Bone and Mineral Research kritériumai}

\begin{tabular}{|c|c|c|}
\hline Major kritérium & Minor kritérium & Kizáró kritérium \\
\hline $\begin{array}{l}\text { - Minimális vagy trauma } \\
\text { nélküli sérülés által } \\
\text { létrejött törés } \\
\text { - Haránt vagy rövid ferde } \\
\text { törés } \\
\text { - Komplett törés mindkét } \\
\text { cortexen kereszül halad, } \\
\text { és medialis csipke- } \\
\text { képzödés látható, az } \\
\text { inkomplett törés csak a } \\
\text { lateralis cortexet érinti } \\
\text { - Nem vagy minimálisan } \\
\text { darabos törés } \\
\text { - Lokális periostealis vagy } \\
\text { endostealis reakció } \\
\text { látható a lateralis } \\
\text { cortexnél a törési } \\
\text { zónában }\end{array}$ & $\begin{array}{l}\text { - A combcsont } \\
\text { diaphysisnél a corticalis } \\
\text { rész megvastagodott } \\
\text { - Unilateralis vagy } \\
\text { bilateralis prodromalis } \\
\text { tünetek, mint tompa } \\
\text { vagy égető fájdalom } \\
\text { a glutealis vagy comb } \\
\text { régiójában } \\
\text { - Bilateralis inkomplett } \\
\text { vagy komplett diaphysis } \\
\text { törés } \\
\text { Elhúzódó törésgyógy- } \\
\text { ulás }\end{array}$ & $\begin{array}{l}\text { - Combnyaktörés } \\
\text { - Intertrochanterikus } \\
\text { törés, amely a } \\
\text { subtrochanter régióba } \\
\text { terjed } \\
\text { - Periprotetikus törés } \\
\text { - Patológiás törés, } \\
\text { amelyet primer } \\
\text { vagy metasztatikus } \\
\text { csonttumor okoz vagy } \\
\text { egyéb csontbetegségek }\end{array}$ \\
\hline
\end{tabular}

\section{MEGFIGYELÉSEK}

2015-ben két betegnél találtunk APFT-re jellemző törésmintázatot. A betegek minor trauma hatására szenvedték el a töréseket.

Klinikánkon a periprotetikus törések rögzítésére leggyakrabban szögstabil lemez rendszereket alkalmaztunk. A lemezeket szükség szerint kiegészítettük cerclage, kábel vagy attachment alkalmazásával. A mútétek után posztoperatív röntgenfelvételek készültek az operált oldalról és az ellenoldalról egyaránt. A mútéteket követő 6., 12., és 52. héten kontroll röntgenfelvételek készültek. Szeptikus szövődményünk nem volt.

\section{ESETISMERTETÉS}

80 éves nőbeteg minor traumára szenvedte el jobb oldali periprotetikus Vancouver B1 típusú törését. $A$ készült röntgenfelvételen atípusos törésmintázat látható: haránttörés, medialis csipkeképződés, minimálisan darabos törés és a lateralis femurcortex megvastagodása (1. ábra). Az anamnézisében hypertonia és postmenopauzális osteoporosis szerepelt, amely miatt 12 évig biszfoszfonátot (alendronsav) kapott. 2010-ben bal oldali középső harmadi femurtörés miatt velőűrszegezés történt (2. ábra). Akkor a radiológiailag és klinikailag is egyértelmú atípusos törés nem került felismerésre, ezért a gyógyszeres terápiában sem történt változtatás. A törés szövődmény nélkül tökéletesen átépült (3. ábra).

2014-ben az implantátumot eltávolítottuk, hogy megelőzzük a fokozott stressz miatti későbbi combnyaktörést. 2015-ben szenvedte el minor traumára jobb oldali atípusos periprotetikus femurtörését. Az atípusos töréseket esetenként előrejelző prodromális combfájdalomról nem rendelkezünk információval. A jobb oldali periprotetikus törés ellátása egy 18 lyukas J\&J DePuy Synthes ${ }^{\circledR}$ LISS DF implantációval történt, két attachment-tel kiegészítve (4. ábra). A posztoperatív időszakban mindkét femurról röntgenfelvételek készültek, amelyeken az ellenoldali femur lateralis cortexén mikrofractura nem igazolódott, csak a korábbi törésből adódó callus. Az ASBMR ajánlás alapján a gyógyszeres kezelést módosítottuk. A korábban alkalmazott alendronate terápiát azonnal felfüggesztettük. Kalcium és D-vitamin kiegészítés mellett teriparatid kezelést indítottunk. A mútét után a beteg panaszmentes volt, operált végtagját tehermentesítve, segédeszközzel közlekedett, valamint aktív és paszszív gyógytornát végzett. A 12 . héten készült röntgenfelvételen a törés jó ütemú átépülését 
láttuk, a beteg panaszmentesen, továbbra is segédeszköz segítségével közlekedett. Az egy

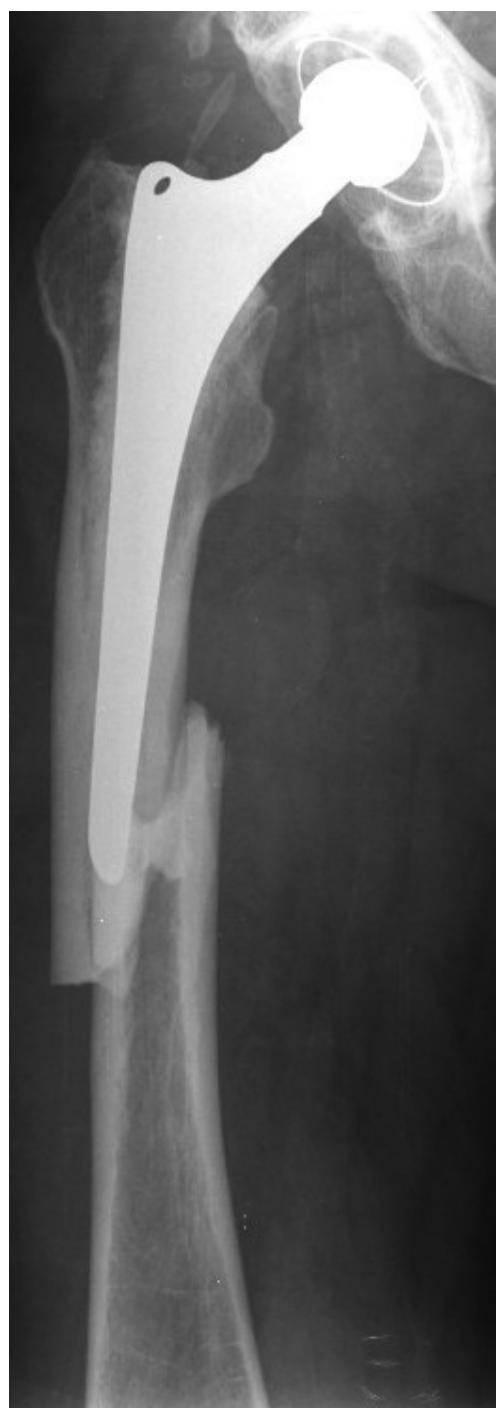

1. ábra

Jobb oldali atípusos periprotetikus törés. Medialis csipkeképződés és lateralis cortex megvastagodás éves kontrollvizsgálaton a törés teljesen átépült (5. ábra).

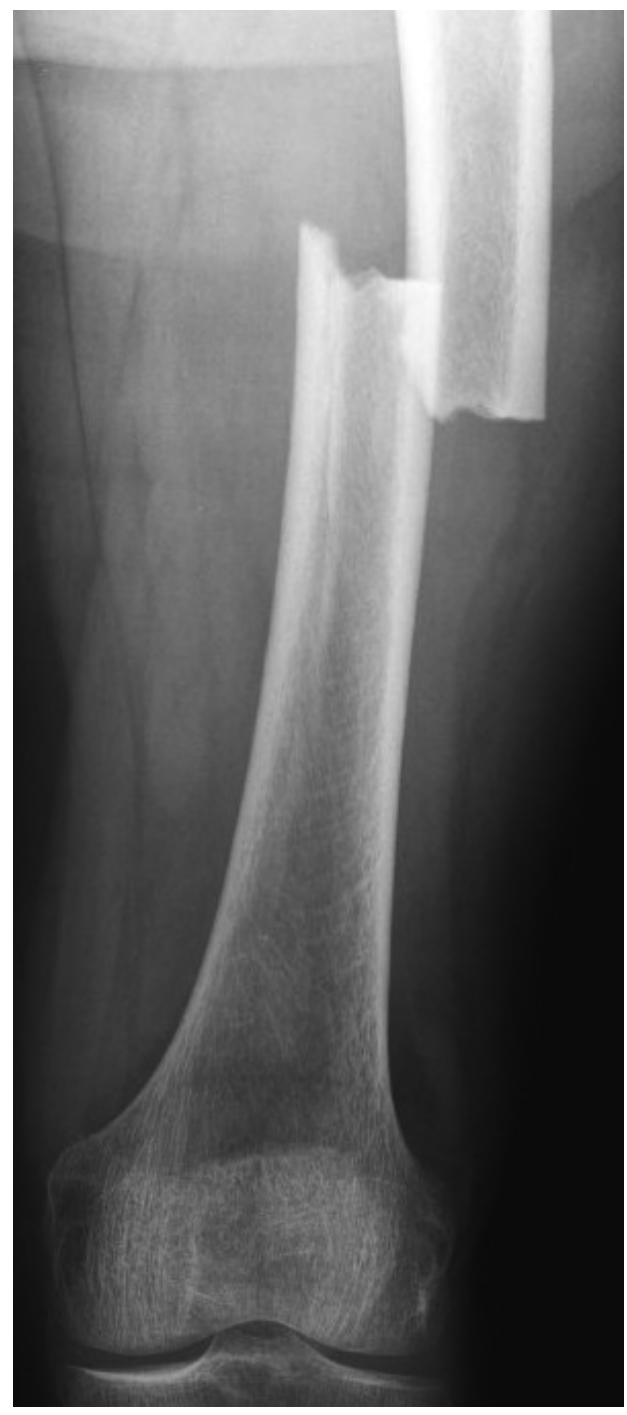

2. ábra

Bal oldali atípusos femur törés 


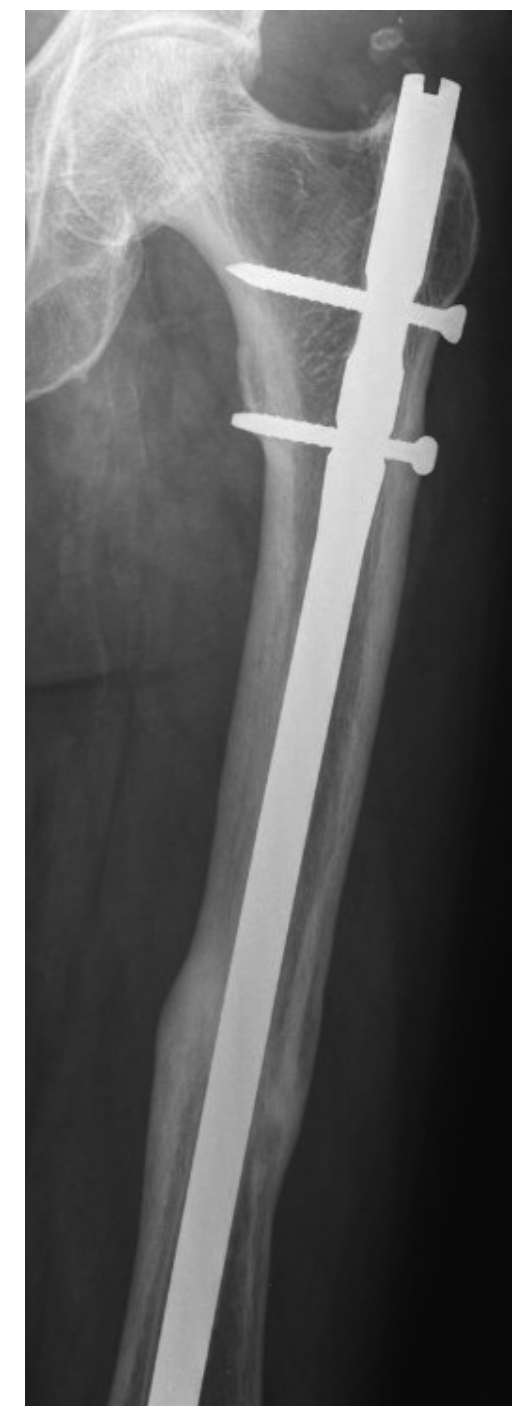

3. ábra

Bal oldali átépült atípusos femur törés

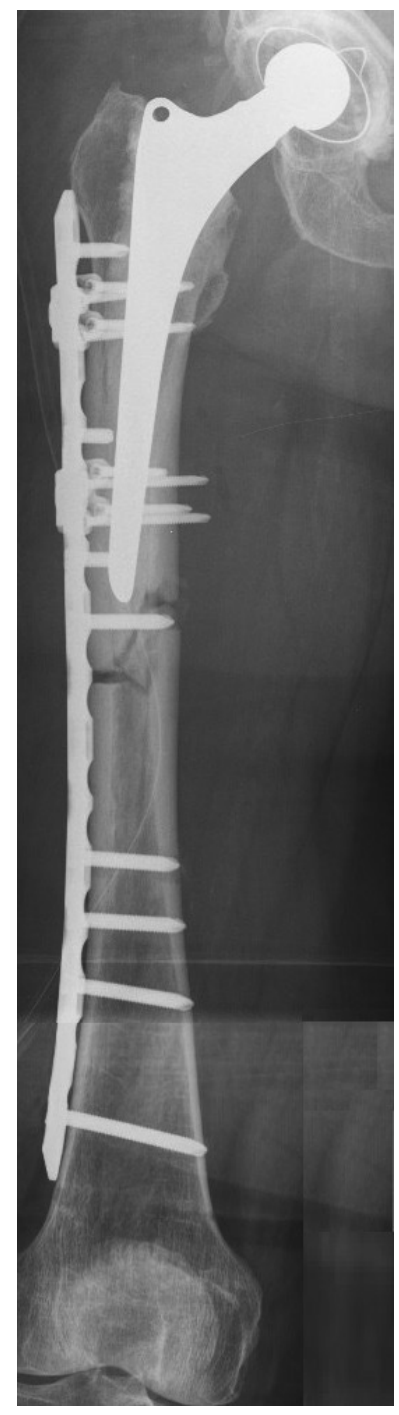

4. ábra

Posztoperativ felvétel a jobb oldali atípusos periprotetikus törés ellátást követően 


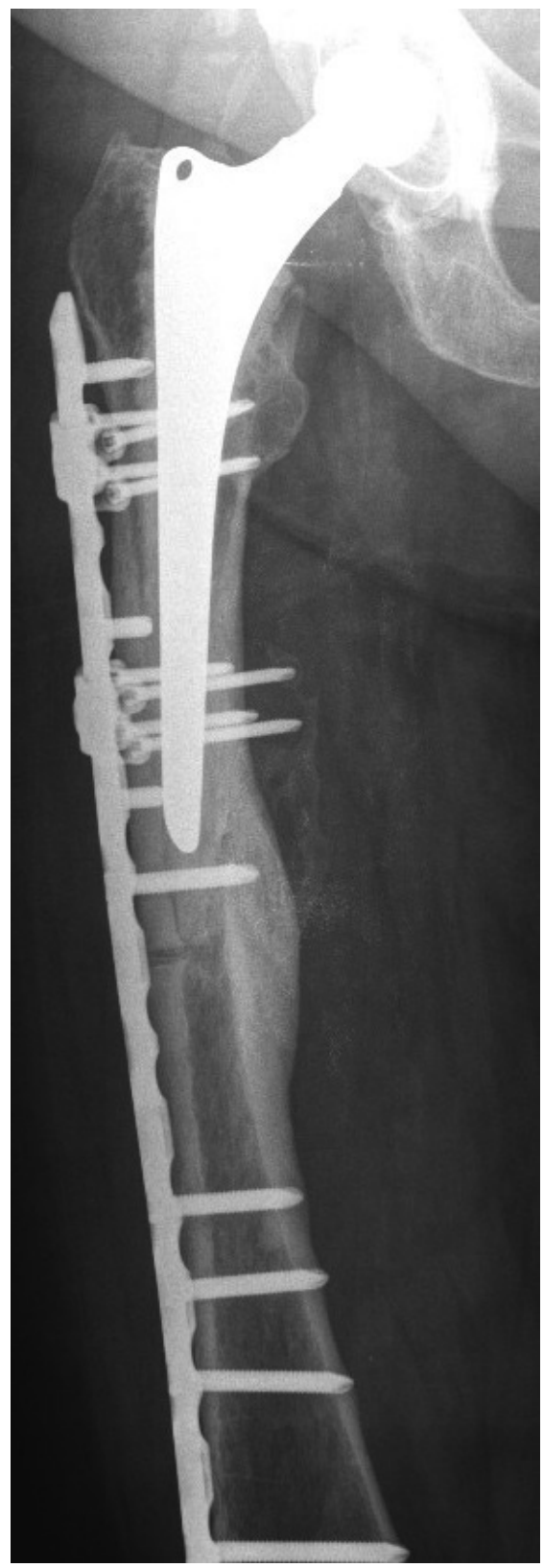

5. ábra

Egyéves kontrollfelvétel a jobb oldali periprotetikus törés átépülése teljes 


\section{MEGBESZÉLÉS}

$\mathrm{Az}$ atípusos femurtörések stressz törésként jelennek meg. Hónapokkal a törés bekövetkezte előtt időszakos combfájdalom jelentkezhet. A radiológiai elváltozások legtöbbször kétoldali megjelenésűek, a lateralis femurcortex megvastagodik, mikrofraktura látható $(2,4)$. Az atípusos femurtörés bekövetkezte esetén ajánlott az ellenoldali femurról is röntgenfelvételt készíteni, mert előfordulhat megvastagodott cortex és mikrofractura, amely előrevetítheti egy jövőbeni törés bekövetkeztét. Bizonytalan esetekben $\mathrm{CT}$ vagy $\mathrm{MRI}$ vizsgálat is megfontolandó (19).

A periprotetikus Vancouver B1 típusú törések mútéti ellátása az $\mathrm{LCP}$ rendszerek alkalmazásán alapul, amely cerclage-zsal, kábellel, illetve a lemezhez rögzített attachment-tel kombinálható. Csonthiány esetén auto- vagy allograft is beültethető a törésgyógyulás elősegítésére, indukálására és stabilabb rögzítés elérésére (11). Az atípusos periprotetikus B1 típusú törések rögzítése nem különbözik a típusos periprotetikus törések rögzítésénél alkalmazott módszerektől, de szem előtt kell tartanunk, hogy az osteosynthesist követően gyakran elhúzódó törésgyógyulás, magasabb mortalitás és több szövődmény fordulhat elő $(13,22)$.

A periprotetikus femurtörések ellátása komoly kihívás elé állítja a baleseti sebészeket, egyre több esettel kell számolni, hiszen egyre több a protetizált beteg (11). Az American Society for Bone and Mineral Research ajánlása alapján a periprotetikus törés, mint kizáró tényező szerepel az atípusos femurtörés esetén.
Ennek ellenére a szakirodalomban, főleg mint esettanulmányok, egyre gyakrabban kerülnek bemutatásra az ilyen típusú törésformák (7, 10, 15, 16, 25). Az ASBMR módosított ajánlása alapján az atípusos törések nem hozhatók szoros összefüggésbe más betegségekkel vagy gyógyszerrel, így a biszfoszfonát tartalmú készítményekkel sem. Az ajánlásban azonban az is megfogalmazódik, hogy a hosszú távú BF alkalmazás és az AFT-ek között összefüggés lehet (22). Egyre több tanulmány igazolja az atípusos femurtörés és a biszfoszfonát használat közötti lineáris összefüggést, főként hosszú távú kezelés esetén ( $>5$ év) $(8,13,24)$.

$\mathrm{Az}$ általunk bemutatott eset is rávilágít az atípusos periprotetikus femurtörések és a hosszú távú biszfoszfonát terápia kapcsolatára.

$\mathrm{Az}$ atípusos törések komplex kezelése nehéz feladat, és az eredmények sokkal szerényebbek, mint a típusos törések esetén. Ennek oka az elhúzódó törésgyógyulás, a rossz csontkonszolidáció, a törésrögzítés nehézsége, a magas mortalitás és a gyógyszeres kezelés szövődményei $(12,17,21)$. A törés megfelelő mechanikai rögzítése mellett rendkívül fontos a törésgyógyulás biológiai elősegítése, a korszerű teriparatid alkalmazása. Periprotetikus Vancouver B1 típusú femurtörés esetén, amenynyiben hosszú távú biszfoszonfát kezelés szerepel az anamnézisben, mindig gondoljunk az atípusos törés lehetőségére. A biszfoszfonátok alkalmazása nagy körültekintést igényel, mindig szem előtt tartva a kezelés előnyeit és hátrányait. Elengedhetetlen a folyamatosan megjelenő új típusú osteoporosis elleni készítmények ismerete és a betegek folyamatos és szoros utánkövetése. 


\section{IRODALOM}

1. Abdel M. P., Watts C. D., Houdek M. T., Lewallen D. G., Berry D. J.: Epidemiology of periprosthetic fracture of the femur in 32644 primary total hip arthroplasties: A 40-year experience. Bone Joint J. 2016. 98-B. (4): $461-467$. https://doi.org/10.1302/0301-620X.98B4.37201

2. Agarwal S., Agarwal S., Gupta P., Agarwal P. K., Agarwal G., Bansal A.: Risk of atypical femoral fracture with long-term use of alendronate (Bisphosphonates): A systemic review of literature. Acta Orthopaedica Belgica. 2010. 76: 567-71.

3. Cross M. B., Nam D., Van Der Meulen M. C. H., Bostrom M. P. G.: A rare case of a bisphosphonate-induced peri-prosthetic femoral fracture. J. Bone Joint Surg. Brit. 2012. 94-B. (7): 994-997. https://doi.org/10.1302/0301-620X.94B7.28778

4. Csonka Á., Gárgyán I., Doró P. Varga E.: Atípusos femurtörés. Magyar Traumatológia Ortopédia Kézsebészet Plasztikai Sebészet. 2014. 57. (2-3): 119-124.

5. Dell R. M., Adams A. L., Greene D. F., Funahashi T. T., Silverman S. L., Eisemon E. O., Zhou H., Burchette R. J., Ott S. M.: Incidence of atypical nontraumatic diaphyseal fractures of the femur. J Bone Miner Res. 2012. 27(12): $2544-2550$. https://doi.org/10.1002/ibmr.1719

6. Franklin J., Malchau H.: Risk factors for periprosthetic femoral fracture. Injury. 2007. 38. (6): 655-660. https://doi.org/10.1016/i.injury.2007.02.049

7. Giannoudis P. V., Kanakaris N. K.: Periprosthetic femoral fractures. In: Lasanianos N. G., Kanakaris N. K., Giannoudis P. V. (Eds.): Trauma and orthopaedic classifications: A comprehensive overview. Stuttgart etc. Springer. 2015. 309-311. pp. https://doi.org/10.1007/978-1-4471-6572-9 69

8. Giusti A., Hamdy N., Dekkers O., Ramautar S. R., Dijkstra S., Papapoulos S. E.: Atypical fractures and bisphosphonate therapy: A cohort study of patients with femoral fracture with radiographic adjudication of fracture site and features. Bone. 2011. 48. (5): 966-971. https://doi.org/10.1016/i.bone.2010.12.033

9. Hollevoet N., Verdonk R., Kaufman J. M., Goemaere S.: Osteoporotic fracture treatment. Acta Orthop. Belg. 2011. 77. (4): 441447.

10. Lee Y., Park C., Kim K., Hong S., Ha Y., Koo K.: Frequency and associated factor of atypical periprosthetic femoral fracture after hip arthroplasty. Injury. 2018. 49. (12): 2264-2268. https://doi.org/10.1016/i.injury.2018.09.014

11. Lindahl H., Malchau H., Herberts P., Garellick G.: Periprosthetic femoral fractures: Classification and demographics of 1049 periprosthetic femoral fractures from the Swedish National Hip Arthroplasty Register. J. Arthroplasty. 2005. 20. (7): 857865. https://doi.org/10.1016/i.arth.2005.02.001

12. Lloyd A., Gludovatz B., Riedel C., Luengo E., Saiyed R., Marty E., Lorich D. G. Lane J. M., Ritchie R. O., Busse B., Donnelly E.: Atypical fracture with long-term bisphosphonate therapy is associated with altered cortical composition and reduced fracture resistance. Proc. Natl. Acad. Sci. 2017. 114. (33): 8722-8727. https://doi.org/10.1073/pnas.1704460114

13. MacKenzie S., Ng R., Snowden G., Powell-Bowns M. F. R., Duckworth A. D., Scott C. E. H.: Periprosthetic atypical femoral fractures exist and are associated with duration of bisphosphonate therapy. Bone Joint J. 2019. 101-B. (10): $1285-1291$. https://doi.org/10.1302/0301-620X.101B10.BJJ-2019-0599.R2

14. Min Y.: Pharmacologic treatment of osteoporosis. J. Korean Med. Assoc. 2016. 59. (11): 847-856. https://doi.org/10.5124/ikma.2016.59.11.847

15. Miura T., Kijima H., Tani T., Ebina T., Miyakoshi N., Shimada Y.: Two cases of periprosthetic atypical femoral fractures in patients on long-term Bisphosphonate treatment. Case Rep Surg. 2019: 2019:9845320. 1-6. https://doi.org/10.1155/2019/9845320

16. Niikura T., Lee SY., Sakai Y., Kuroda R., Kurosaka M.: Rare non-traumatic periprosthetic femoral fracture with features of an atypical femoral fracture: A case report. J Med Case Rep. 2015: 9:103. https://doi.org/10.1186/s13256-015-0590-z

17. Prasarn M. L., Ahn J., Helfet D. L., Lane J. M., Lorich D. G.: Bisphosphonate-associated femur fractures have high complication rates with operative fixation trauma. Clin. Orthop. Relat. Res. 2012. 470. (8): $2295-2301$. https://doi.org/10.1007/s11999-012-2412-6

18. Reyes C., Hitz M., Prieto-Alhambra D., Abrahamsen B.: Risks and benefits of Bisphosphonate therapies. J. Cell Biochem. 2016. 117. (1): 20-28. https://doi.org/10.1002/icb.25266

19. Robinson J., Leighton R., Trask K., Bogdan Y., Tornetta P.: Periprosthetic atypical femoral fractures in patients on long-term Bisphosphonates: A Multicenter retrospective review. J. Orthop. Trauma. 2016. 30: $170-176$. https://doi.org/10.1097/BOT.0000000000000508

20. Russell R., Watts N., Ebetino F., Rogers M.: Mechanisms of action of bisphosphonates: Similarities and differences and their potential influence on clinical efficacy. Osteoporos. Int. 2008. 19. (6): 733-759. https://doi.org/10.1007/s00198-007-0540-8

21. Schilcher J.: High revision rate but good healing capacity of atypical femoral fractures. A comparison with common shaft fractures. Injury. 2015. 46. (12): 2468-2473. https://doi.org/10.1016/i.injury.2015.09.031

22. Shane E., Burr D., Abrahamsen B., Adler RA., Brown T. D., Cheung A. M., Cosman F., Curtis J. R., Dell R., Dempster D. W., Ebeling P. R., Einhorn T. A., Genant H. K., Geusens P., Klaushofer K., Lane J. M., McKiernan F., McKinney R., Ng A., Nieves J., O'Keefe R., Papapoulos S., Howe T. S., van der Meulen M. C., Weinstein R. S., Whyte M. P.: Atypical subtrochanteric and diaphyseal femoral fractures: Second report of a task force of the American society for bone and mineral research. J. Bone Mineral Res. 2014. 29. (1): 1-23. https://doi.org/10.1002/ibmr.1998

23. Szathmári M.: A csonttörés kockázatának megítélése osteoporosisban. Orv. Hetil. 2011. 152. (33): $1304-1311$. https://doi.org/10.1556/OH.2011.29191 
24. Szövérfi Zs., Farkas G. L. Á.: Hosszú távú biszfoszfonátkezelés alatt jelentkező atípusos femurtörés: mellékhatás vagy véletlen egybeesés? LAM KID. 2012. 2. (1): 23-29.

25. Woo S. B., Choi S. T., Chan W. L.: Atypical periprosthetic femoral fracture: A case report. J. Orthop. Surg. 2016. 24. (2): 269272. https://doi.org/10.1177/1602400230

\section{Dr. Csonka Ákos, Ph.D.}

6725 Szeged, Semmelweis u. 6.

Tel.: +36 705550304

Fax: +36 62545113

csonka.akos81@gmail.com 